\title{
COMMENTS
}

\section{THE COMPETENCE OF STUDENTS AS EDITORS OF LAW REVIEWS: A RESPONSE TO JUDGE POSNER}

\author{
NATALIE C. COTTON ${ }^{\dagger}$ \\ INTRODUCTION
}

Judge Richard Posner and others have critiqued American law reviews for being run by students. ${ }^{1}$ They claim that students do not have

${ }^{\dagger}$ J.D. \& M.B.A. Candidate, University of Pennsylvania; Executive Editor, Journal of Animal Law \& Ethics, Vol. 1; Senior Editor, University of Pennsylvania Law Review, Vol. 154. I especially thank Ruth Sternglantz, J.D. 2005, Articles Editor, University of Pennsylvania Law Review, Vol. 153, for graciously helping me to think through this project. Though this Comment has been strengthened by many who have offered comments and critiques, the ideas (and mistakes) represented here are my own.

This Comment does not represent the opinions, policies, or procedures of the University of Pennsylvania Law Review, the Journal of Animal Law E Ethics, or their editors, except where noted.

${ }^{1}$ Judge Richard Posner, James Lindgren, and Roger Cramton have been perhaps the most energetic critics of the role of students in law reviews.

Posner's most recent critique is subtitled, "Welcome to a World Where Inexperienced Editors Make Articles About the Wrong Topics Worse." Richard A. Posner, Against the Law Reviews, LEgAL AfF., Nov.-Dec. 2004, at 57, 57 [hereinafter Posner, Against Law Reviews]; see also Richard A. Posner, The Future of the Student-Edited Law Review, 47 STAN. L. REV. 1131, 1132 (1995) [hereinafter Posner, Future of the Law Review] (arguing that law students are not capable of evaluating and editing interdisciplinary articles).

Professor Lindgren has viciously attacked student editors in several articles. See James Lindgren, Student Editing: Using Education To Move Beyond Struggle, 70 CHI.-KenT L. REV. 95, 95 (1994) [hereinafter Lindgren, Student Editing] ("We've asked [students] to do a task that they are incompetent to do. And then we've given them essentially no supervision.”); James Lindgren, An Author's Manifesto, 61 U. CHI. L. REV. 527, 527 (1994) [hereinafter Lindgren, Manifesto] ("Our scholarly journals are in the hands of incompetents.”); James Lindgren, Fear of Writing, 78 CAL. L. REV. 1677, $1678-79$ (1990) [hereinafter Lindgren, Fear of Writing] (reviewing TEXAS LAW REVIEW MANUAL ON STYLE (6th ed. 1990) and WEBSTER's DicTIONARY OF ENGLISH USAGE (1989)) (attacking the style book published by the Texas Law Review and describing students as incapable of anything but zombie-like adherence to rule books). He has also appealed to other professors to take charge of the editing process and not accept bad editing: "When [students] step over the line and we don't tell them, they feed on our weakness 
the necessary depth of knowledge that faculty have, nor the requisite experience editing scholarly work. ${ }^{2}$ In many cases, the students reviewing or editing an article have no knowledge whatsoever of the article's topic, nor any experience at all editing another's work. As a result, it is said, students are ill-prepared to take on the collective role of "gatekeeper" to America's legal scholarship. If this is true, the value of student-run law reviews must inhere in some nonscholarly aspect, such as providing a recruiting mechanism for employers. ${ }^{3}$

This argument seemingly creates an anomaly: law is a broad and important discipline, yet the organizations that publish its scholarship are geared toward nonscholarly goals, and are not competent to address the scholarly ones. If this is indeed the case, it is a wonder that

and grow stronger.... As victims of student editing, we shouldn't remain silent." James Lindgren, Student Editing, supra, at 100. His criticism, however, has toned down as he has, perhaps, found working to change law reviews a more rewarding task. See James Lindgren, Reforming the American Law Review, 47 STAN. L. REV. 1123, 1125-29 (1995) [hereinafter Lindgren, Reform] (suggesting several ways to involve faculty in law reviews, in order to address the three "problems" of student-edited reviews: editing, article selection, and supervision of students).

Further back in time, Professor Cramton also criticized the role of students in legal scholarship. See Roger C. Cramton, "The Most Remarkable Institution": The American Law Review, 36 J. LEGAL EDUC. 1, 7 (1986) [hereinafter Cramton, Remarkable Institution] ("The other premise, that legal scholarship would be well served by student editorship, was always shaky, but the modern evolution of legal scholarship has demolished it entirely.”); Roger C. Cramton, Faculty-Edited Law Reviews: Yes, SyLlabus, Sept. 1985, at 1, 3 [hereinafter Cramton, Faculty-Edited Law Reviews] ("The claim that student editors can recognize whether scholarly articles make an original contribution is a pretense that should no longer be tolerated.").

Other professors have also contributed. See, e.g., Arthur D. Austin, The "Custom of Vetting" as a Substitute for Peer Review, 32 ARIz. L. REV. 1, 2-4 (1989) (describing the practice of students editing professors as the "skeleton" in the law family closet, "an embarrassing situation deserving the smirks of disdain it gets from colleagues in the sciences and humanities"); Bernard J. Hibbitts, Yesterday Once More: Skeptics, Scribes and the Demise of Law Reviews, 30 AKRON L. REV. 267, 291 (1996) ("[T] he concept of law students exercising quality control over legal scholarship borders on the oxymoronic.").

${ }^{2}$ See Posner, Future of the Law Review, supra note 1, at 1132 (noting that law reviews "labor under grave handicaps" because "their staffs are composed primarily of young and inexperienced persons working part time: inexperienced not only as students of the law but also as editors, writers, supervisors, and managers"); Hibbitts, supra note 1, at 292 (" $[\mathrm{T}]$ here's a great deal of legal and non-legal ground about which they know nothing [and] they have taken on an evaluative task for which they are simply not prepared."). However, Professor Hibbitts also notes that "traditional quality control by peers may not be that much better," and describes many of the problems that other fields have had with peer review. Id. at 292-94.

${ }^{3}$ See Max Stier et al., Project, Law Review Usage and Suggestions for Improvement: A Survey of Attorneys, Professors, and Judges, 44 STAN. L. REV. 1467, 1487-90 (1992) (providing survey results indicating the importance attorneys and judges place on law review membership as a hiring factor). 
the "atrocities perpetrated by law review editors" ${ }^{4}$ are not more widely protested. But this cannot be the case.

This Comment argues that, while students do encounter challenges in running scholarly publications, they are quite competent to select and edit legal scholarship. Students do have low knowledge depth, and the capabilities of individual students vary considerably. However, law reviews as organizations have created processes that make these weaknesses of students much less significant. Student-run publications achieve their scholarly goals by publishing a portfolio of articles—and do so regularly.

That is not to say the law reviews are perfect. To the extent that specialized knowledge and editorial experience confer unique efficiencies, ${ }^{5}$ these are efficiencies that most student-run publications cannot capture. However, other efficiencies are created through the process of checking for article preemption and multiple-round editing. These efficiencies outweigh the negative repercussions of having students as the gatekeepers to America's legal scholarship.

Part I of this Comment presents the criticisms that Judge Posner and others have advanced, with some initial thoughts about what that implies for the fundamental role of law reviews. Part II presents the article selection process in light of Judge Posner's critique, while Part III addresses the concerns of many professors that article placement is critical to one's career. Part IV reviews the editing process, especially in light of criticisms by Judge Posner and others. In conclusion, I maintain that, by their processes and procedures, law reviews contribute to a robust and innovative body of legal scholarship.

The reasoning and argument in this Comment encompass all student-run legal publications. Previous literature on student publications addresses "law reviews," but in this context the term is often used

\footnotetext{
${ }^{4}$ Posner, Future of the Law Review, supra note 1, at 1132.

${ }^{5}$ One might question in which contexts these efficiencies are created. Professor Epstein has noted that as faculty editor, he has been able to attract submissions from those with whom he works best, which seems very efficient. See Richard A. Epstein, Faculty-Edited Law Journals, 70 CHI.-KENT L. REv. 87, 89 (1994) ("If I sense that an author and I will not get along-whether because of differences in temperament or in intellectual orientation-I will not accept an article... The reputation that one acquires, both as an editor and a scholar, exerts a useful sorting effect on the pieces that are submitted for review."). However, this method closes publication opportunities to those who have greater differences of opinion with the faculty editor. If every publication operated in this way, legal scholarship as a whole would be inefficient-barriers to divergent ideas would hamper its growth. However, within a system of both faculty and student journals, Professor Epstein's efficiencies may prove valuable to both his journal and scholarship as a whole.
} 
as a catchall for both general-scope law reviews and specialty law journals. This Comment will also use the term "law review" broadly, referring to all scholarly student-run legal publications.

\section{JUDGING LAW REVIEWS}

\section{A. Complete Incompetence?}

It is widely assumed that authors, especially professors seeking tenure, care where they place articles. This is because the prestige of the journal in which an article is placed is somehow a signal of the article's quality. As Professor Hardy notes, "the academic profession, the practicing bar, and judges, all tend to treat articles in certain reviews with more respect than others." ${ }^{6}$ But why?

Some commentators emphasize that student-run law reviews exist for educational or other purposes. ${ }^{7}$ If education of student editors is the purpose of the institution of law review, and these editors are not competent to select and edit articles, then it cannot be meaningful or prestigious to publish in any particular law review. ${ }^{8}$ No matter how good an educational experience a review gives its members, this does not directly benefit authors; consequently, that element cannot explain why authors so covet placement in the Yale Law Journal or the Harvard Law Review. Moreover, the extent to which law reviews help employers (including judges) select students also cannot explain a law review's prestige among authors.

So, where does this prestige come from? Does it only come from the prestige of the hosting school itself? This cannot be the case, for, in the hands of incompetents, even the most prestigious journal should lose some of its value. If students were incompetent to select

\footnotetext{
${ }^{6}$ Trotter Hardy, Review of Hibbitts's Last Writes?, 30 AKRON L. REV. 249, 251 (1996).

${ }^{7}$ Harold Havighurst, who made the famous comment that " $[\mathrm{w}]$ hereas most periodicals are published primarily in order that they may be read, the law reviews are published primarily in order that they may be written," noted that " $[t]$ he principle value [of law reviews] comes from the training which the superior students receive in writing the notes and comments." Harold C. Havighurst, Law Reviews and Legal Education, 51 Nw. U. L. REV. 22, 24 (1956).

8 "To be published, even cited, in an Ivy League law review is considered to be a feather in one's professional cap. To be spurned by the East Parsipanny Journal of Nursery School Law, on the other hand, is ignominy most bitter...." Kenneth Lasson, Commentary, Scholarship Amok: Excesses in the Pursuit of Truth and Tenure, 103 HARV. L. REV. 926, 948-49 (1990). Professor Hardy notes that "it is not enough to observe that students do not really do a good job of quality control, when in fact the legal community acts to the contrary." Hardy, supra note 6, at 252.
} 
articles-or if they decimated articles during editing-then an immediate loss in quality would show. The "wrong" articles would be published. Certainly, legal academics, at least, are discriminating enough to tell. So, it simply cannot be that students are incompetent in running scholarly journals. ${ }^{9}$ The long-standing and little-changing hierarchy of prestige among authors maintained by law reviews is proof itself.

It may be that the true critique of law reviews is not that they are entirely incompetent, but that individual mistakes are too numerous-that students are generally competent, but their error rate is too high. Put more fully, Harvard Law Review publishes superb scholarship on average, but in any given volume there is an article or two that "shouldn't be there." The error rate is low enough such that scholarship published in law reviews produces valuable contributions to legal scholarship, but at a level that makes critics wonder whether the system is optimal. This critique is more logical; I take this to be the idea underlying the critique advanced by Judge Posner.

\section{B. The Posner Critique: Interdisciplinary Incompetence}

Specifically, Posner states that " $[\mathrm{m}]$ ost articles by law professors today are still, as they were a century ago, rather narrowly, conventionally doctrinal.... Good law students can evaluate and improve such articles today as always. But ... many law faculty today have, for good or ill, broken the doctrinal mold." ${ }^{10}$ He argues that students have sufficient exposure to doctrinal analysis to be competent as editors of law review articles that focus on such analysis, once the breadand-butter of law reviews.

\footnotetext{
${ }^{9}$ In fact, a 1991 survey revealed that professors evaluated law reviews as rather modestly meeting their scholarly goals, which include stimulating academic interest, suggesting theoretical frameworks for analysis, and identifying new approaches or developments in specific legal topics. See Stier et al., supra note 3, at 1495 ("The responses certainly do not establish that law reviews are wildly successful at achieving any of the listed goals. But neither do they support a finding that law reviews fail to meet any of those same goals."). The survey is over a decade old, and the sample size of professors was under one hundred; yet it helps show that even when law reviews are criticized for being inadequate, many still find them useful. Unsurprisingly, survey "[p]articipants who had published in student-edited journals were more likely to support student selection of articles than were those who had published in other journals." Id. at 1504; see also id. at 1502-04 (reporting survey results showing that the majority of attorneys, professors, and judges approve of having students edit law reviews).

${ }^{10}$ Posner, Against Law Reviews, supra note 1, at 57.
} 
However, when it comes to interdisciplinary topics, Posner says, law students are not competent to select publishable articles, complaining that their error rate is too high. "The principal nondoctrinal subfields of law are economic analysis of law, critical legal studies, law and literature, feminist jurisprudence, law and philosophy, law and society, law and political theory, critical race theory, gay and lesbian legal studies, and postmodernist legal studies." ${ }^{11}$ Posner believes that students are not prepared to handle any of these subjects, and as a result, student editors are "now dealing with a scholarly enterprise vast reaches of which they [can] barely comprehend." ${ }^{12}$

At the least, says Posner, to sustain the value that student-run law reviews bring to legal scholarship, law reviews should accept doctrinal articles only. ${ }^{13}$ Other critics have advocated changing the dominant

${ }^{11}$ Posner, Future of the Law Review, supra note 1, at 1133.

${ }^{12} I d$. Others have voiced similar concerns in the past. See Cramton, Faculty-Edited Law Reviews, supra note 1, at 3 (noting that "the myth of the omnicompetent generalist lawyer" has no validity concerning theoretical and interdisciplinary scholarship, since even "the most experienced and able faculty members do not claim competence over the entire realm of legal scholarship"). Almost two decades ago, Professor Cramton declared that "[1] aw today is too complex and specialized . . . and legal scholarship is too theoretical and interdisciplinary" for students to be competent as editors. Cramton, Remarkable Institution, supra note 1, at 7. In 1955, Professor Arthur Nussbaum stated:

Labor law, taxation law, corporation and trust law, public control of business, etc., are steadily developing new and intricate problems; legal philosophy is being paid far more attention than in the past; [then-current international relations have made necessary] ... investigation of international and foreign law. Students may not have acquired the knowledge and maturity to handle those trends adequately as independent editors.

Arthur Nussbaum, Some Remarks About the Position of the Student-Editors of the Law Review, 7 J. LEGAL EDUC. 381, 381 (1955).

${ }^{13}$ In all fairness, I should say that Posner recommends that law reviews have a presumption in favor of doctrinal scholarship, and that they use referees for interdisciplinary articles. Posner, Future of the Law Review, supra note 1, at 1136. The effect-and intent-of this suggestion would be to decrease dramatically the number of interdisciplinary articles published in student-edited reviews.

Another perspective on the proper focus of law reviews came from Judge T.S. Ellis, who argued that, while students should focus on practical developments in the law, whether doctrinal or interdisciplinary, they should leave lofty theoretical matters to faculty-edited journals. See T.S. Ellis, III, Student-Edited and Faculty-Edited Journals in the Marketplace of Legal Ideas: A Reply to Professor Dekanal, 57 UMKC L. REv. 246, 247 (1989) (discussing the distinct niches of student-edited and faculty-edited law reviews). 
law review form by increasing faculty supervision, ${ }^{14}$ or moving away from student editorship altogether. ${ }^{15}$

Underlying the opinions of Posner and others seems to be the assumption that if students select the "wrong" articles for publication, legal scholarship is harmed. Scholars will be deceived if they assume that all articles published in a top-tier law review are fully vetted and excellent papers. Moreover, it has been pointed out that when faulty empirical research is published, scholars end up wasting time rebutting the published work and exposing its errors. ${ }^{16}$

To be sure, legal scholarship would be harmed if students selected articles that were so ill-conceived that they did not present valid theses or used erroneous methodologies. As suggested in Part I.A, however, it is unlikely that students are selecting articles far outside the realm of

${ }^{14}$ See Randy E. Barnett, Beyond the Moot Law Review: A Short Story with a Happy Ending, 70 CHI.-KENT L. REv. 123, 130-31 (1994) (suggesting that faculty become more involved in the reviews at their schools). Professor Lindgren has also stated:

[W] e must begin to take responsibility for the monster that our predecessors

created. We should begin to reassert control over the law reviews. This in-

cludes formally instructing student editors at our own schools about the

proper role of editors of scholarly journals. We should encourage a maxi-

mum role for faculty in article selection.

Lindgren, Manifesto, supra note 1, at 535; see also Posner, Against Law Reviews, supra note 1 , at 57 ("Ideally, one would like to see the law schools 'take back' their law reviews, assigning editorial responsibilities to members of the faculty. Students would still work and write for the reviews, but they would do so under faculty supervision."); Lindgren, Reform, supra note 1, at 1125-29 (proposing several models for faculty involvement); Jonathan Mermin, Remaking Law Review, 56 Rutgers L. REV. 603, 621-22 (2004) (arguing that faculty should have input in the article selection process); $c f$. Afton Dekanal, Faculty-Edited Law Reviews: Should the Law Schools Join the Rest of Academe?, 57 UMKC L. REV. 233, 234 (1989) (suggesting that since faculty involvement has declined, so has the quality of law reviews); John G. Kester, Faculty Participation in the Student-Edited Law Review, 36 J. LEGAL Educ. 14, 15-16 (1986) (same). But see James W. Harper, Why Student-Run Law Reviews?, 82 MINN. L. REV. 1261, 1289-93 (1998) (rebutting Professor Lindgren's arguments for faculty involvement in student-run reviews).

${ }^{15}$ There have been many calls for faculty-edited law reviews. See, e.g., Cramton, Faculty-Edited Law Reviews, supra note 1, at 3 (suggesting that law reviews should be completely faculty-run, although students might be permitted to edit articles in a student note section). Professor Hibbitts has advocated doing away with journals completely and self-publishing on the web. Bernard Hibbitts, Goodbye to All That?: The Provenance and Prospects of the Law Review, 28 LAW LIBR. 134, 137 (1997).

${ }^{16}$ See Michele Landis Dauber, The Big Muddy, 57 Stan. L. Rev. 1899, 1910-11 (2005) (arguing that Stanford Law Review's publication of a highly controversial antiaffirmative action article was a mistake, requiring scholars to spend time investigating and refuting the article's thesis). Professor Dauber believes that Richard H. Sander's article, A Systemic Analysis of Affirmative Action in American Law Schools, 57 STAN. L. REv. 367 (2004), would not have been published but for the lax standards of law review article selection, and that the American media's subsequent publicizing of the article has been harmful to the American public. Id. at 1911-12. 
acceptable scholarship. Though many may disagree over the worth of an article, such pieces can still positively contribute to legal scholarship. For example, the conclusions that are drawn from empirical research are often subject to interpretation. Just because an article's premises may be challenged does not make the article invalid.

This Comment asserts that students are fully competent to identify valid articles, whether doctrinal or interdisciplinary. An article is valid if its conclusions follow logically from its premises. Although a reader might not ultimately be convinced of the substance of the article's argument, it is nonetheless sound. To say that students are competent to identify valid articles does not mean that students are competent to identify the "best" scholarship among submissions. Frankly, ranking articles for "correctness" and "significance" of content is dangerous business; these are such subjective measures that it is difficult to avoid making decisions based on one's own interests or academic leanings. Even among professors, evaluation of any given article would vary.

\section{Differing Conceptions of the Meaning of Article Placement}

Posner's criticisms also appear to rely on an assumption that law reviews do (and should) exist within a strict hierarchical structure, in which the most meritorious of articles are published in the most prestigious of reviews. According to this view, where an article is placed in that structure is meaningful; a well-written and well-founded article merits higher placement among law reviews. If students actually place an article lower than it should be placed, then the students of the higher ranked law review rejecting the article have erred. However, a system in which law reviews only publish scholarship appropriate to their tier in the hierarchy is merely an ideal. Not only do assessments of quality vary among individual professors, but the readership also includes legal practitioners, whose own assessments of article quality vary as well. Given the subjective nature of quality, is there any reason why there should be a rigid hierarchy of publications according to quality?

Law reviews respond to this difficulty by striving to collect a portfolio of strong, varied articles, all the while recognizing the necessary difference of opinion about overall quality that is inherent in the process. Law reviews compete by trying to attract the best portfolio of articles-the best collection among submissions that would appeal to varied critical readers. Not every article will make every reader happy. Instead of harming legal scholarship, such a system encourages a more robust body of scholarship. When student editors "err" in arti- 
cle selection, this can allow controversial ideas to surface for discussion, allowing alternative perspectives and methodologies to be analyzed and critiqued. This is of great benefit to legal scholarship.

It also means, of course, that the quality of every article is not always equal to the prestige of the law review in which it appears, despite the fact that the prestige of the journal on the whole depends on the overall combined quality of articles selected. Reader beware: critical thinking should not be abandoned when opening the covers of the Harvard Law Review. Readers can be confident, however, that no matter how controversial an article is, Harvard Law Review editors have ensured that it at least presents a valid argument.

In sum, to the extent that the Posner critique rests on the ideal of having a rigid hierarchy of law reviews where only the most meritorious interdisciplinary articles are published by the top reviews, that critique is misguided. The issue is not whether students are competent to select only the "best" articles, but whether student editors are able to determine whether a given article meets a basic threshold of validity, thereby creating a portfolio of valid articles for dissemination to the legal community.

\section{ARTiCle SELECTION}

Much of the criticism of law reviews is directed specifically at the article selection process. First, critics charge that students are "not well equipped" to select articles, because they lack expertise in a broad array of subjects. ${ }^{17}$ The articles submitted cover so many areas of law and other fields that there is a low probability of having even one editorial board member with sufficient background knowledge. Moreover, even if some students have been exposed to a field, they have not yet developed the skills necessary to evaluate its scholarship. Modern articles focus more on theory, and refined theoretical arguments that draw on philosophy, economics, and other social sciences require a different analytical toolset than that taught in law classes. ${ }^{18}$

${ }^{17}$ See supra note 2. But see John Paul Jones, In Praise of Student-Edited Law Reviews: A Reply to Professor Dekanal, 57 UMKC L. REV. 241, 242 (1989) ("Even if professing has given us some expertise useful in evaluating ideas in manuscripts, that expertise is relatively narrow. ... To hew to a standard of editing by subject matter experts, a law review run by professors would have to limit its scope, or enlist the entire faculty for the editorial board.").

${ }^{18}$ See Posner, Against Law Reviews, supra note 1, at 58 (declaring that since the "analytical core" of interdisciplinary fields of legal studies is not legal, "the law review 
The result, says Posner, is that "many interdisciplinary articles are published that have no merit at all."

In addition, others have argued that student independence prevents consultation of faculty for assistance in selecting articles. ${ }^{20}$ Instead, students use arbitrary measures for selection ${ }^{21}$ or base decisions on personal topical preferences. ${ }^{22}$ Especially for reviews that receive several hundred or more manuscripts, ${ }^{23}$ the selection process "must" be arbitrary. ${ }^{24}$

First, it is helpful to describe what the selection process seeks to identify. The critique of student capability may sound sensible to many: because the article selection process is complex, anyone young and inexperienced will have difficulty with it. The truth is, however, that article selection is not too difficult a task for law students. Decid-

editor cannot get much mileage from what he or she has learned about legal reasoning").

${ }^{19} I d$.

${ }^{20}$ See Jordan H. Leibman \& James P. White, How the Student-Edited Law Journals Make Their Publication Decisions, 39 J. LEGAL EDUC. 387, 390 n.21 (1989) (“[T] he critics of the institution of law review appear to assume a low or nonexistent faculty input into the article selection process. In our study of current practices, however, we found substantial faculty input at the better-known schools.").

${ }^{21}$ Posner points out that students can "indulge their whims, and thus ... publish the 'tenure article' of a junior professor-not because it was a good article but because he was a popular teacher or the editors felt sorry for him and did not want to see him fired." Posner, Against Law Reviews, supra note 1, at 57. Especially because students are not able to weigh the merits of interdisciplinary articles, selection criteria are now made up of political and other inappropriate criteria, such as the reputation of the author, the author's politics or host school, the "author's commitment to genderneutral grammatical forms, ... a desire for equitable representation for minorities and other protected or favored groups, the sheer length of an article, [and] the number and length of the footnotes in it ...." Posner, Future of the Law Review, supra note 1, at 1133-34 (footnote omitted). Lindgren concurs that students are more impressed by longer articles with more footnotes. See Lindgren, Manifesto, supra note 1, at 531 ("[T] he extraordinary length of most legal articles is a reflection of the need to impress students.”). But see Top Law Reviews To Limit Length of Articles, TaxProf Blog, http://taxprof.typepad.com/taxprof_blog/2005/02/top_law_reviews.html (Feb. 8, 2005) (describing the commitment of eleven law reviews to shorter article lengths).

${ }^{22}$ See Carl Tobias, Manuscript Selection Anti-Manifesto, 80 CORNELl L. REV. 529, 530 (1995) (" $[\mathrm{M}]$ ost editors possess strong predilections and act on them compulsively when making publication offers. One set of substantive preferences involves hot, trendy or cute topics.").

${ }^{23}$ The University of Pennsylvania Law Review receives approximately 2000 submissions annually. About the Law Review, University of Pennsylvania Law Review, http://www.pennlawreview.com/history.php (last visited Feb. 20, 2006).

${ }^{24}$ In explaining why article selection is unpredictable, Professor Tobias says that "[t] oo few articles editors, who have too little time and too little understanding... must review too many pieces, too few of which the law journals can publish." Tobias, supra note 22 , at 530 . 
ing whether or not an article is desirable is not an elusive process requiring a refined professional judgment, honed through years of apprenticeship and experience. It is not even like wine tasting or artgallery visiting, where a certain kind of "taste" or "eye" is needed.

In fact, article selection is more like exam grading. Students often complain about the "randomness" of grades-or about their inaccuracy. ${ }^{25}$ Professors assert that grades are useful in identifying whether students understand and can apply certain concepts. Since students realize that essay exam responses vary in so many ways, they conclude that the process of grading must be complex and prone to error. Professors respond by describing their systems for grading, of which there are many. They claim that since the metrics used to assign grades are clearly identified and evaluated individually, the process is more scientific and reliable than students think. And, they point out, the good exams and bad exams are easy to identify. It is only the ones in the middle that are difficult. ${ }^{26}$

Similarly, by identifying the attributes that are desirable for articles and evaluating them along those dimensions, student editors easily eliminate many from consideration and sort the remainder. ${ }^{27}$ When we consider exactly how the selection process works, the issue is demystified, and the question becomes whether students are capable of evaluating the individual criteria that comprise a desirable scholarly article.

Generally, editors selecting articles look for those that are appropriate for their particular law review, have a high quality of scholarship, and are timely and interesting. ${ }^{28}$ Whether editors are students or

${ }^{25}$ See E. Joshua Rosenkranz, The Empire Strikes Back, 22 ST. MARY’s L.J. 943, 947 (1991) ("[G] rades so often have so little to do with how much a student has prepared or how well she knows the material that it all seems futile ....").

${ }_{26}$ " $[\mathrm{T}]$ here are close calls at the margin. There is no bright line between a B and a B+. But that does not make the entire process flawed and arbitrary." Michael Vitiello, Journal Wars: Obi-Wan Kenobi Speaks, 22 ST. MARY's L.J. 927, 933 (1991). This is precisely the point about article selection.

${ }^{27}$ But see Erik M. Jensen, The Law Review Manuscript Glut: The Need for Guidelines, 39 J. LEGAL EDUC. 383, 383 (1989) (noting that because multiple simultaneous submission is allowed, there are just too many articles to consider in a disciplined fashion "even after the chaff has been discarded," regardless of whether the consideration is done by students or faculty).

${ }^{28}$ I have developed these criteria based on my own opinions and observations as an editor of two law reviews, discussions with others who have been involved in the article selection process, and a survey of literature available on article selection. See Telephone Interview with Ruth Sternglantz, Articles Editor, University of Pennsylvania Law Review, Vol. 153 (Dec. 25, 2004) (discussing law review management and article selection processes); Interview with Indraneel Sur, Articles Editor, University of Penn- 
faculty, these criteria are important and appropriate. ${ }^{29}$ The following sections describe each of these three main requirements and whether students are indeed capable of evaluating them. Note that what follows describes the general process that law reviews use and shows how that system makes the article selection process effective toward the goals discussed in Part I.

\section{A. Appropriateness}

It may seem too obvious, but not all scholarly articles are appropriate for law review publication, and this is determined by both the targeted audience and general character of each publication. Articles must have an appropriate scope of issues and should be relevant to the review's geographical reach. An article addressing a specific point of law may be preferable to those reviews with a more specialized focus, and articles addressing overall changes in a field of law will be more desirable to reviews with a more general focus. These considerations stem from the law review's own identity, and students are as competent to evaluate them as more experienced scholars. ${ }^{30}$

Another important element of the appropriateness of an article is its understandability. Since law reviews have a wider readership than other fields' journals, ${ }^{31}$ an esoteric article that would be understand-

sylvania Law Review, Vol. 153, in Phila., Pa. (c. Jan. 21, 2005) (discussing the ideas in a previous draft of this Comment); infra note 63 (providing citations to articles discussing selection criteria). The selection criteria enunciated in this paper generally comport with the criteria described by those I have interviewed, however the analysis is my own and may not reflect the opinions of those individuals. Similarly, the criteria are not reflective of the policies of the University of Pennsylvania Law Review or the Journal of Animal Law E् Ethics. The University of Pennsylvania Law Review has not enunciated a policy for article selection, and the Journal of Animal Law $\mathcal{E}$ Ethics has not yet developed one.

${ }^{29}$ In order to achieve these goals, a number of elements must be considered. For example, to be of sufficient quality, an article must be well-written, unique, wellresearched, and well-analyzed (logical and valid).

${ }^{30}$ In arguing for a more limited role for faculty involvement in the article selection process in Canadian law reviews (where faculty involvement is the norm) former Alberta Law Review Editor-in-Chief Larissa Katz emphasizes that students are "[f]amiliar with the history of the review, its recent and upcoming publications, and most importantly its mission, [and] they are in the position to say that a particular kind of paper on a particular topic meets the law review's peculiar criteria and thus should be published." Larissa Katz, The Law Review Mission: A Student Editor's Point of View, 39 ALTA. L. REV. 684, 686 (2001). She points out that "a [faculty] reviewer is not responsible for the internal consistency and the direction of a law review." Id. Therefore, she believes, a faculty reviewer should not be used to make the ultimate publication decision. Id.

${ }^{31}$ See Dolores K. Sloviter, Commentary, In Praise of Law Reviews, 75 TEMP. L. REV. 7, 7 (2002) ("Law reviews play different roles for readers in different positions. They are 
able only to experts might not be appropriate, ${ }^{32}$ even if it were groundbreaking and timely. Students are particularly well-equipped to evaluate this point. An article that is intelligible to a student editor will "make sense to a tax lawyer who needs to understand the implications of a family law doctrine, or to a recent judicial appointee who spent twenty years doing securities work .... It will also be accessible to any academic, no matter how specialized that academic has become." ${ }^{33}$

\section{B. Quality of Scholarship}

Concerning the quality of the piece, it is important that the article be well-written and unique. While these qualities are subjective, students are not at a disadvantage in discerning writing quality, ${ }^{34}$ and the well-developed "preemption check" process reveals whether a thesis is unique. In fact, here is where process is designed to overcome the limits of student knowledge.

Upon first read, a student may not know whether an idea is fresh. Before a law review will accept the piece, however, the student who champions the piece must troll through the previous literature in the topic to specifically identify whether the idea has been developed before. This can be time-consuming, but happily, legal literature is wellindexed. For those articles addressing nonlegal topics, the student's task is harder, but not impossible. There are many resources available to law students to research interdisciplinary topics. ${ }^{35}$

a source of commentary on legal issues for legal scholars, practitioners, students, and judges."); see also Stier et al., supra note 3, at 1483-84 (presenting the results of a survey of attorneys (Stanford alumni), judges, and professors that reveals that professors consult law reviews most frequently).

${ }^{32}$ See Harper, supra note 14, at 1285-88 (arguing that, because it serves practical purposes, legal scholarship should not be esoteric); Phil Nichols, Note, A Student Defense of Student Edited Journals: In Response to Professor Roger Cramton, 1987 DukE L.J. 1122, 1130 (1987) (" $\mathrm{I}] \mathrm{t}$ is important that law review material be accessible to its larger audience.").

${ }^{33}$ Nichols, supra note 32, at 1130; see also Harper, supra note 14, at 1287 ("Where better to guard against complexity and murkiness in the law than uniquely suited student-run law reviews?").

${ }^{34}$ Accepting for the sake of argument that students are not good writers, one doesn't have to be a good writer to know good writing. See Henry H. Perritt, Jr., Reassessing Professor Hibbitts's Requiem for Law Reviews, 30 AKRON L. REV. 255, 256-57 (1996) ("[O]ne can make an equally persuasive argument that good writing can be appreciated by those without unusual levels of specialized education and experience.”).

${ }^{35}$ In addition, there are techniques which make this search easier. For instance, a good starting place is often the sources cited within the article itself-these will likely point to references to begin the preemption check. 
The important point here, though, is that even if students are at a disadvantage in absorbing the interdisciplinary background material of an article, they are still fully capable of discovering whether a thesis has already been published. A full grasp of the finer points of a published theory is not necessary to be able to compare it to the article's thesis. $^{36}$

From an expert's perspective, this process is inelegant, crude, and seemingly inefficient. It takes much longer for a student to identify the uniqueness of the article than an expert, and even after the busywork of looking up prior articles, the student does not become an expert; the knowledge needed to judge originality is gathered last minute, and only to the degree necessary. From the perspective of the law review, on the other hand, this process is actually efficient. Time is not spent becoming an expert, but rather, developing familiarity with the material sufficient to distinguish the article under consideration from prior work.

It is true that articles are regularly published that are not completely unique. If done well, those articles that summarize and rehash prior debate can be useful to scholarship as a tool for readers' research. Also, articles that present old theories in a new light can be useful in spurring further developments in legal scholarship. This is recognized by both student- and faculty-run journals. It may be that students choose greater numbers of "less" unique articles than faculty editors, either due to differing emphases on the criteria above or, for some reviews, to the unavailability of better alternatives. This is not the same, however, as stating that students are less capable of ascertaining the uniqueness of an article-students do know the difference, but consider the degree to which the article makes a big or small leap from existing literature to be one factor among many when selecting articles.

The next elements of quality that must be assessed are whether the article is well-researched and well-analyzed. By well-researched, I mean that the article sufficiently documents assertions and facts that are found elsewhere and that the references correctly represent their

${ }^{36}$ But see William G. Ross, Scholarly Legal Monographs: Advantages of the Road Less Taken, 30 AKRON L. REv. 259, 262 (1996) ("Although student law review editors presumably do a pre-emption check of every article that they seriously consider for publication, student editors may not have enough expertise to place the significance of an article in its proper perspective."). However, Professor Ross's standards may be too high, since he says that "even the faculty member who is the most knowledgeable about a subject is unlikely to have the depth of expertise of the typical reviewer for a book publisher...." Id. at 263. 
sources. Well-analyzed means that the article's argument is logical and valid. An argument that misleads, neglects strong counterarguments, or is simply wrong, would not be valid. An interdisciplinary article that reflects an economic theory that has been discredited, for example, would not be valid.

Unfortunately, assessing how well-researched an article is prior to editing the article is a truly difficult task. From the law review editor's perspective, it is also one of the most important issues to assess as early as possible, since often the law review staff must bear the burden of addressing research deficiencies. ${ }^{37}$ Students are competent to identify whether an article is not sufficiently researched-that is, whether it is missing documentation to support ideas and facts ${ }^{38}$ - but for the most part, it is during the editing phase that any problems in how well the piece was researched surface. Yet it would seem that faculty editors of general scope journals would have this problem as well. ${ }^{39}$ After all, the typical article covers a great number and variety of sources that would be outside of the mental recall of a professor who does not specialize in the topic. Not only will the specific topic at issue be covered in dozens or more predecessor articles, but an article may use over a hundred sources overall; this Comment draws on over fifty sources, as an example.

${ }^{37}$ See Terri LeClercq, The Nuts and Bolts of Article Criteria and Selection, 30 STETSON L. REV. 437, 438 (2000) ("[S] ome journals edit only egregious errors after they have accepted an article; some journals provisionally accept an article and require the author to make changes, while other journals actually offer organizational changes or content changes."). My own observations are similar: some reviews address research deficiencies, while others do not. As an associate editor of the University of Pennsylvania Law Review, I provided a small amount of research for articles. However, as an executive editor of the Journal of Animal Law Eं Ethics, I have declined to do so. See Journal of Animal Law \& Ethics Editorial Policy (on file at the Journal of Animal Law \& Ethics) (describing a policy of not performing substantive research assistance). At any rate, it is a controllable variable for law reviews. Manpower is limited, but the research deficiencies of most articles can be reasonably addressed. Efficiency and morale are the only issues here, and both are well served by early identification of research needs.

${ }^{38}$ But see Alan Hall, Cite Makes Wrong: An Argument for Changing Law Review Editorial Procedure for Checking Scientific Facts, LegAL REFERENCE SERVS. Q. 10(4), at 5, 6-10 (1990) (arguing that law review editors should go further than plain cite-checking to verify the quality of assertions of scientific fact).

${ }^{39}$ With a faculty-edited specialty journal, one would imagine that editors would have a certain familiarity with often-cited sources and recent publications that may be addressed by an article. Yet, it is an open question whether this familiarity would lead to the early identification of research deficiencies (improper references, misrepresentation, etc.) in the majority of such specialty articles; likely these problems would also arise later in the editing phase, as with general-scope journals. 
It deserves pointing out that law reviews, whether article selection is done by students or faculty, have come to accommodate this difficulty: the law review itself corrects research deficiencies after accepting the article. Students, like research assistants, work to fill in gaps in documentation and correct mischaracterizations. ${ }^{40}$ However, this has created an inappropriate incentive for authors, who can, with varying degrees of reliance, shift research tasks onto unpaid students. ${ }^{41}$ One might consider this to be good or bad-perhaps the research tasks are educational for students, and perhaps not. However, there is a strong argument that research efforts should be devoted more toward the students' own work rather than toward other authors' work; at the least, editing should not so overwhelm staff that the quality of student notes and comments suffers. Some reviews react by refusing to perform extensive work for authors. ${ }^{42}$

Yet this can compromise the scholarly goal of law reviews. If avantgarde articles requiring extra research assistance are not accepted, or if good articles that were accepted prior to learning that research was deficient were not improved, then this would harm scholarship as a whole. In the event that a law review publishes material with obvious errors, the law review itself would suffer a blow to its reputation. ${ }^{43}$ So, a balance is needed, and each review currently struggles to strike one. Perhaps further thought and experimentation is needed to find ways to lessen the burden of research on law review staff. ${ }^{44}$

${ }^{40}$ See Mermin, supra note 14, at 604 ("While law professors do hire some research assistants, dozens of students at each American law school serve as research assistants for free. These students do not labor under the title of 'research assistant,' but are instead dubbed 'editors' of the law review.").

${ }^{41}$ See id. at 611 ("What has to this point escaped general notice is the extent to which many professors have abused this 'useful service,' leaving it to student editors to do, not just check . . . substantial portions of their work." (emphasis omitted)).

${ }^{42}$ See, e.g., Commentary, A Response, 61 U. CHI. L. REV. 553, 557-58 (1994) (announcing a policy of selecting only finished articles).

${ }^{43}$ There is, of course, some delay when it comes to changes in reputation, and reviews with high reputations can afford some goofs. However, publishing material that is poorly researched does affect the reputation of any law review. Some authors assume that since "their name[s]" alone are on their pieces, that the article reflects on them only. See Carol Sanger, Editing, 82 GEO. L.J. 513, 516 (1993) ("[W] hen authors sign their names to their work, they take responsibility publicly and professionally for what they have written."); $i d$. at 525 ("Editors do not include on their resumes the titles of the pieces they edited, with before and after versions appended."). Yet the law review's name is on the entire issue. While student editors themselves do not acquire reputations from their editing, the law review as an institution certainly does.

${ }^{44}$ Earlier identification of problems would help address the burden. For example, several sources in the document could be found just after article acceptance. If problems are revealed, the law review could request that the author take a closer look at the 
Students' ability to assess whether an article is well-analyzed is perhaps the most controversial element of article selection. Part of this criterion includes assessing how logical the arguments are. Given the wide readership of reviews, ${ }^{45}$ it is appropriate for students to evaluate logical consistency and flow. ${ }^{46}$ The heart of the critique is that, if students do not understand the material, it is impossible to evaluate its logic. Yet, if the material is presented in a hard-to-understand manner, it should be rejected as being inappropriate for the practical and educational audience. ${ }^{47}$ This is not to say that law-review-published scholarship should be limited in scope. Much that is complicated and theoretical can still be explained to a reader with no prior specialized knowledge $^{48}$-it just may take more explanation. ${ }^{49}$

article and revise before the editing began. Also, the review might require that when an article requires substantial research assistance, the article contain a note recognizing the specific students who contributed. Law reviews should consider the ethics of the current nonrecognition of research services. Cf. Robert M. Jarvis, Law Review Authors and Professional Responsibility: A Proposal For Articulated Standards, 38 DRAKE L. REV. 889, 896 (1989) (including in his proposed Model Rules of Professional Conduct for Law Review Authors a duty to reveal the use of research assistants and "the ways in which the work has been altered by the law review staff").

${ }^{45}$ See supra note 31.

${ }^{46}$ Cf. supra note 33 and accompanying text. Legal training prepares students for this especially well; after all, the ability to make and evaluate arguments logically is a skill useful to debate within any field, which is why the J.D. is considered to be a valuable generalist degree. The first year is the critical period for learning this skill, making second- and third-year students-although not expert-competent for the job.

${ }^{47}$ See supra note 32 and accompanying text. But see Sanger, supra note 43, at 519 (stating that the actual readers of law reviews know more than students about the topics addressed in articles, such that the "assumed congruence of identity between editor and reader is mismatched"). Since many use articles as an introduction to a topic, Professor Sanger's point seems applicable only to part of the readership base, leaving students as the "least common denominator." See Stier et al., supra note 3, at 1485 (" $[\mathrm{W}]$ hereas professors rarely used law reviews to gain a general overview of existing law, attorneys valued law reviews ... as an alternative to treatises for summarizing the law in a particular area.").

48 "Communicating clearly, however-even about complex legal ideas-should not be an impossible task." Lasson, supra note 8, at 944 . Moreover, "if our purpose as scholars is to explain and persuade, we are most likely to succeed if we write simply and clearly." Id. at 948.

${ }^{49}$ Law reviews have often been criticized for having excessively lengthy articles. See Sloviter, supra note 31, at 9 (noting that the length of articles makes it difficult for judges such as herself to read them). However, this has nothing to do with student incompetence; it is due to the law review's role as a general, wide-readership periodical. Even if students were out of the picture, practitioners and judges are generalists who need well-explained articles to help with their own analysis and research. In this sense, law reviews have evolved in a manner most appropriate for this goal-by increasing student involvement, reviews are best able to ensure quality control. See Nichols, supra note 32, at 1129-30 ("[S] tudent editors are perhaps more qualified to edit pieces than 
In terms of how well-analyzed an article is, the trickiest part for students is assessing an article's validity. How would students know, for example, that an economic theory relied on in the article has become obsolete $?^{50}$ The short answer is that the preemption check should provide enough knowledge to assess whether-at the least-the thesis of the article has been discredited. A proper preemption check should also reveal sources that provide support for the thesis. The goal, of course, is not to determine whether a thesis is "correct," but whether it is valid. ${ }^{51}$ A reader will ask herself whether an article espouses the right perspective; an editor generally should not.

Cast in this way, the assessment becomes more like the question of whether the article "fits" with the existing scholarship, as revealed by the preemption check. It fits better if other articles' theses do not render implausible its own assertions. Some threshold level of fit makes an article valid. The emphasis on validity comes from the fact that it is not necessary for an article to be "correct"-fully convincing and unchallengeable-in order to contribute to the development of scholarship. Again, valid but imperfect perspectives can lead to greater and more significant scholarship (either as follow-up or rebuttal). ${ }^{52}$ Even if a thesis purports to contradict current understandings, there still must be a level of "fit" such that the thesis provides a logical account. Students performing the preemption check can assess this. ${ }^{53}$

their faculty counterparts would be [because] steps in the analysis have to be explained, and insider jargon and shorthand eliminated.").

${ }^{50}$ Professor Tobias has declared that too " $[\mathrm{m}]$ any law journals thus publish articles premised on works by thinkers whose ideas have long since lost their cachet-or have even been discredited." Tobias, supra note 22, at 530 .

${ }^{51}$ Scholarship is best served by reducing the editors' substantive judgment during article selection as much as possible; otherwise, law reviews would have a more biased selection process, for which faculty-led journals in other fields have been criticized. See, e.g., Hibbitts, supra note 1, at 292-95 \& nn.101-18 (providing a thorough critique, with references, of peer review processes used across academia). Substantive judgment should be limited to whether the topic is appropriate and timely, the argument logical, and the perspective valid.

${ }^{52}$ Only if a review receives more than one well-written, appropriate, unique, and sufficiently researched manuscript addressing the same topic should a question be raised as to which article is more convincing.

${ }^{53}$ The issue remaining is whether it is sufficient for only one student to do the preemption check. Much hinges on the knowledge learned from the process. In effect, law review boards may make final decisions on appropriateness, understandability, logicality, sufficiency of research, and quality of writing, while delegating uniqueness and the validity of the analysis to individual members. There may be ways to make the process more effective; for instance, by requiring a preemption memo submitted to the full selection board summarizing major issues found. I would encourage something 
The limitation of the preemption check, however, is that it is only addressed to the main thesis of the article. Secondary assertions not within the specific field of the thesis are not typically tested. ${ }^{54}$ As a result, it is quite possible that students do not realize when secondary nonlegal assertions are invalid. ${ }^{55}$ To be more specific, this will happen when the thesis of the article is a legal thesis, but secondary assertions are interdisciplinary. ${ }^{56}$

To some extent, there is leeway in the analysis of whether an article is valid. Ultimately, the concern is whether the main thesis is valid, but this may or may not depend on the validity of any given secondary assertion. A judgment call is necessary, and the student doing the preemption check should consider expanding the preemption check to major secondary assertions in other disciplines.

In sum, to be well-analyzed, an article must be both logical and valid. This is a broader definition of "well-analyzed" than many might give. $^{57}$ In fact, it places greater weight on how well the arguments in articles are constructed (which students can readily assess) than whether articles have applied the best framework for analysis (which

more substantive than the checklist from the Texas International Law Journal, see LeClercq, supra note 37, at app. C, but that approach is a step in the right direction.

${ }^{54}$ For example, if an article's thesis concerns tort liability, then the preemption check requires scanning articles in the area of tort liability sufficient to provide knowledge to verify secondary assertions in tort theory. However, this would not provide enough knowledge to check a secondary assertion in, say, theories regarding the psychology of human behavior.

${ }^{55}$ Of course, many students $d o$ have prior education in other fields, and legal education can at times give interdisciplinary exposure. However, it does not make sense to rely on such possible exposure. On the other hand, Posner's apparent requirement of a Ph.D. in order to understand a field is extreme: "Except for the rarefied set of Ph.D.s who go to law school for a J.D., the disciplines on which these [interdisciplinary] fields draw are generally not ones about which a law review editor will be knowledgeable, except by accident." Posner, Against Law Reviews, supra note 1, at 58. Exposure and understanding are the necessary elements, and they are fostered at the undergraduate and masters levels.

${ }^{56}$ If the main thesis is interdisciplinary, the preemption check would include researching the non-law discipline involved, so secondary assertions in that area can be tested for validity.

${ }^{57}$ See Lasson, supra note 8, at 941-42, for an argument that in the context of promotion and tenure, the requirement that a scholars' work be analytical is hard to define and has been applied too subjectively. Professor Lasson recommends a broader definition of "analytical," to include "that which describes a body of knowledge, and offers an opinion about it.' The true measure of an article's quality should be how well it describes the subject, how tautly it is written, and how cogent we think the opinioneven if we disagree." Id. at 942. The criteria for articles enunciated in this Comment are compatible with Professor Lasson's perspective, in the sense that they try to avoid the problems he identifies. 
takes more subject matter expertise to assess). As I have tried to make clear, current student knowledge bolstered by the knowledge gained in the preemption check create a threshold for the latter-requiring use of a valid framework for analysis.

\section{Other Criteria}

Once an article is determined to be appropriate, understandable, well-written, unique, well-researched, and well-analyzed, ${ }^{58}$ it must also be assessed for timeliness and interest value; that is, is this a "hot topic?"59 Or at least, an interesting topic? Many articles which are published are not hot, but are nonetheless interesting in the sense of being relevant to current legal and social development. Judge Posner has cautioned that it is unnecessary for reviews to aspire to "mak[e] their review more 'timely' in the sense of being more likely to be read cover to cover upon publication." ${ }^{60}$ I agree; however, law review articles should be timely in the sense that they are more likely to be used in current research and debate.

The assessment of what constitutes a hot topic is necessarily a subjective decision and one that introduces the most room for arbitrariness in the process. However, the inquiry of this Comment is whether students are competent to fulfill their roles as editors. In fact, students are perhaps best positioned to make this assessment. What is a timely or interesting topic varies among a law review's diverse readership. ${ }^{61}$ Students receive signals from each type of actor within the legal landscape and are not already devoted to specific fields and types of analysis. ${ }^{62}$ As a result, students are competent to evaluate timeliness and interest value.

\footnotetext{
${ }^{58}$ For a top law review, which receives a deluge of submissions, only a small percentage of submissions meet this combined threshold. See A Response, supra note 42, at 555 ("The stark truth is that authors submit many articles that do not meet basic criteria of logic and clarity.").

${ }^{59}$ I refer to "hot topic" in the sense that there are topics about which many scholars and practitioners currently would like to write and read, or which currently come before courts and legislatures.

${ }^{60}$ Posner, Future of the Law Review, supra note 1, at 1137.

${ }^{61}$ Note that law reviews as a body of scholarship have certainly been criticized for being unable to serve the needs of such diverse readers. See, e.g., Stier et al., supra note 3 , at 1470 (citing comments of judges who believe that legal scholarship has moved away from the interests and needs of the courts). Some articles have evolved towards more scholarly work, while law reviews overall continue to be used by practitioners. Accordingly, I will assume that satisfying diverse readers is possible.

${ }^{62}$ This point has been made in the literature. See, e.g., Nichols, supra note 32, at 1127 ("A second advantage is that one viewpoint can never capture student-edited law
} 


\section{The Evaluation Process}

Many articles offices may not articulate their standards in the same way as I have; however, the basic emphases appear to be universal. $^{63}$ What often does vary is the relative weight given to each criterion; this varies across reviews and within articles offices. ${ }^{64}$ Moreover, two different individuals or two different reviews may use the same criteria but still rate a given article differently. Although the criteria considered are the same as those outlined here, how important each criterion is considered (varying weights) and how consistently each criterion is rated (varying evaluations) do alter overall evaluations. So there might seem to be a certain randomness in the process because evaluations of the same article may vary considerably from law review to law review.

The first concern, that of varying weights, is partly an inevitable result of the fact that individuals-whether students or faculty-do not agree on the proper role and value of scholarship. This, of course, is a benefit to scholarship, since it means that a greater variety of articles are published (for example, articles that emphasize practical communication and articles that emphasize innovative theory). Varying em-

reviews."). I wish only to point out that not only are students not "captured" individuals, but also their proximity to professors and practitioners creates competence to sense hot topics that can serve each community. In many classes, professors take time to indicate hot topics, either to share with the class their current work, to indicate possible student comment topics, or to relate the course material to future work as practitioners. In my personal experience, students also devote an incredible amount of time during the first year assimilation period and the second year recruiting process-not to mention during summer internships-to learning about emerging topics in the law. It helps them to answer a question that may be on their minds: "Do I really want to be a lawyer?" Major court decisions and media references to legal and legislative issues are discussed among students. No student will have a full grasp of everything hot or interesting, but information is readily exchanged and debated.

${ }^{63}$ A 1989 study publishing the results of interviews of law review editors, revealed that many reviews did not formally articulate standards for assessing manuscripts. Leibman \& White, supra note 20, at 413-16. However, "[t]here was more internal agreement (among editors from the same journal) than external, and the high-impact journals more often emphasized innovation, sophistication, and theory." Id. at 415; see also LeClercq, supra note 37, at apps. A, B, \& C (providing guidelines for article evaluation from the Texas Review of Litigation, the Texas Journal of Women and the Law, and the Texas International Law Journal).

${ }^{64}$ See Liebman \& White, supra note 20, at 415 ("Our overall conclusion was that different individuals subscribed to widely varying priorities .... As a result, for journals that require high consensus before extending publication offers, articles have to garner very high marks along a wide spectrum of evaluative standards in order to succeed."). 
phases on different requirements might also be partly the result of a lack of clarity about what is needed.

Readers might prefer that law reviews place higher priorities on uniqueness, logicality, and other aspects, and less weight on the degree to which articles are well-researched. This is what critics mean when they say that students are incompetent "because" they pick articles based on whether they conform to The Bluebook. ${ }^{65}$ These critics are confusing the issue-it is not a matter of competence in evaluating articles, it is a matter of mismatched priorities. In comparing the importance of one criterion, whether the article uses the appropriate format, versus another criterion, such as how innovative the article is (uniqueness), some students might prioritize format higher than critics would like. Regardless of whether it is a worthy prioritization, critics should not think that students are not capable of recognizing innovation. Instead, we should encourage appropriate feedback and law reviews should take this feedback seriously.

The second concern, that of varying evaluations, raises the critique that students' error rate is too high. There are two components to this concern-that student evaluations are both inaccurate (not the same as faculty evaluations) and highly variable. This draws a distinction between accuracy and precision. Critics might claim that students' evaluations of articles are inaccurate because they are "wrong," and have not come to the same evaluation that a faculty member might have. Or they might claim that evaluations by different students are so variable (imprecise) that the process can't be legitimate.

However, faculty evaluations are also highly variable. Given that faculty are only part of the readership base, it is not clear why their evaluations should be the standard for accuracy. I have commented earlier that, on the whole, law reviews publish scholarship that is valued, and many reviews do so consistently enough to have high prestige. As a whole, the system error rate in accepting desirable articles is exceedingly low. Then what's the problem? It seems to be that since the journal's prestige rubs off on its articles' prestige, authors want the individual error rate of high prestige reviews to be exceedingly low. ${ }^{66}$

${ }^{65}$ The Bluebook: A Uniform System OF Citation (Columbia Law Review Ass'n et al. eds., 18th ed. 2005).

${ }^{66}$ See Vitiello, supra note 26, at 937 ("I contend that few first rate articles cannot find a home in a student run journal. I believe that much of the 'evidence' [of rejection of first rate articles] is anecdotal based on [the] highly biased frustration of scholars whose articles are rejected by top ranking journals." (emphasis added)). 
In essence, authors want high prestige reviews to take authors' interests into account. However, from a scholarly publication's perspective, whether a law review is run by students or faculty, authors' personal interests are irrelevant. A review must seek to maximize its own prestige, which is created by the quality of the complete portfolio of articles it publishes. As long as the portfolio as a whole meets the goals of the review, rejecting a high quality article in favor of a lower quality article is not necessarily an error. ${ }^{67}$ The higher quality article will be published elsewhere, and the legal community may judge for itself the worth of the lower quality article.

In sum, students are competent to evaluate articles because they can competently evaluate each of the criteria listed above. If "misjudgments" are made, they do not harm the reviews or legal scholarship. Reviews have different processes for their final decisions, ${ }^{68}$ yet the criteria reasonably limit the pool of articles that get consideration. As a result, the goals of article selection do not require prior specialized knowledge. In implementing the described processes, specialized knowledge sufficient to evaluate the uniqueness and validity of submissions is acquired.

What is crucial for this process to work well, however, is enough time to perform a sufficient preemption check. For many law reviews, competition for articles is fierce, and time is in short supply. Especially when authors request expedited review with a deadline of twenty-four or forty-eight hours, the preemption check can be compromised, unless it is already in progress. The crucial disadvantage that student-run law reviews face, then, arises from an operational challenge. Although other perspectives ${ }^{69}$ and considerations ${ }^{70}$ exist,

${ }^{67}$ But, if this prestige-maximizing behavior results in any worthy articles not being published, then the behavior is a disservice to legal scholarship. As mentioned earlier, however, I assume that all good manuscripts are published somewhere. See supra note 65 .

${ }^{68}$ For a summary of some of the alternatives, see Leibman \& White, supra note 20, at $402-10$.

${ }^{69}$ Some law reviews may view the process as a series of calculated risks, with the expectation that the end selection of articles will contain both unique and non-unique, or valid and invalid, theses. The goal then would be to attract as many great articles as possible-by spending less time on preemption checks and being first to make an offer-without ensuring that all articles meet a quality threshold. This could be a good technique for improving the reputation of a law review that has not had success in attracting great articles; however, it may do a disservice to legal scholarship to the extent that invalid theses are still published. This strategy reflects not on the fact that law reviews are student-run, but on the fact that there are too few great articles compared to the number of reviews. An option worth considering is to publish an issue containing only student work when valid "leading articles" are not available. See Douglas B. Maggs, 
law reviews should avoid accepting articles only after spending appropriate time making an informed decision.

\section{Why ARTicle Selection SHOuld Not Be AFFECTED BY THE TENURE PROCESS}

Now that the article selection process has been dissected, it should be clear that it is not analogous to the evaluation processes that faculty appointments and tenure committees use in identifying top scholarship. To meet the needs of a student-run journal, an article must be valid; to meet the needs of appointments and tenure committees, scholarship must not only be valid, but rigorous. ${ }^{71}$ That is, an article is valid if it is logical-its conclusions follow logically from its premises. However, an article is rigorous if it is both logical and compelling or cogent.

Certainly, every law review hopes to attract the best scholarship, just as every law faculty hopes to attract the best scholars. Moreover, even though the prestige of law reviews depends on attracting the best articles, the stakes are very different. Accepting "second-rate" scholarship for publication in one of six issues per year is not as significant a problem as accepting a "second-rate" scholar to be a colleague for many years. To put it bluntly, appointments and tenure committees at the top law schools must be more scrupulous and value-driven than the reviews that their schools house. The error rates that they can tolerate are different.

Considering this difference, law schools should not consider the "hierarchy" of reviews in which a candidate's articles were published when hiring faculty members. ${ }^{72}$ Instead, appointments and tenure

Concerning the Extent to Which the Law Review Contributes to the Development of the Law, 3 S. CAL. L. REV. 181, 190 (1930) ("If articles worth printing are not available, why not publish an issue without leading articles?”).

${ }^{70}$ Depending on the circumstances, the reputational advantage of publishing a well-respected author may outweigh the possible disadvantage of a nonunique work. Similarly, prior knowledge of students may be sufficient to prove that a thesis is valid, making a preemption check (and "learning" a new topic) less crucial for acquiring specialty knowledge.

${ }^{71}$ See Lasson, supra note 8, at 935 ("For purposes of promotion and tenure, 'scholarship' means written and published materials which meet all of the following criteria: they are 'analytical,' 'significant,' 'learned,' 'well-written,' and 'disinterested.'” (citing various faculty handbooks)). These terms are not easily defined, as Professor Lasson points out, but "significant" and "learned," at a minimum, require more than simple validity.

${ }^{72}$ But see Gregory Scott Crespi, Ranking the Environmental Law, Natural Resources Law, and Land Use Planning Journals: A Survey of Expert Opinion, 23 WM. \& MARY ENVTL. 
committees should evaluate scholarship without regard to where it is published, for the best scholarship is not published only in the top reviews, and the top reviews don't publish only the best scholarship. But, for some reason, it is thought that faculties might use article placement as a proxy for article quality. ${ }^{73}$

Thus, one reason professors might dislike the system of studentrun law reviews is because they fear that students' selection of articles will influence professors' careers. The sense is that students at law schools such as Harvard, Yale, Columbia, and the University of Pennsylvania do professors a disservice by not selecting only the best articles. ${ }^{74}$

At the risk of overly speculating, perhaps committees might use article placement as a proxy for quality because individuals on committees might not always have the time or expertise to fully evaluate other scholars' work. $^{75}$ The idea that specialty expertise is lacking among faculty members, with important ramifications for peer evaluation, resonates in an older article by Judge Posner:

Doctrinal analysts, who still dominate most law schools, are not in a good position to evaluate the work of social scientists or of lawyers using social science methods. This introduces a random element into the appointment and promotion process. Some individuals who may not be good social scientists are appointed and promoted because they impress the

L. \& POL'Y REV. 273, 280, 290 (1998) (providing rankings of specialty journals because "scholars who seek to obtain tenure and promotion may improve their prospects somewhat by publishing their work in the most prestigious journals possible").

${ }^{73}$ See id. at 273 ("Persons [conducting tenure and promotion review] who fail to do thorough evaluations of their colleagues' scholarship instead often rely heavily upon the reputation of the publishing journals as a proxy for the quality of the work."); Russell Korobkin, Ranking Journals: Some Thoughts on Theory and Methodology, 26 FLA. ST. U. L. REV. 851, 858 (1999) ("Whereas one or two articles published in highly prestigious journals might win the author tenure or a healthy pay raise, more articles published in less prestigious journals might be needed to secure the same rewards."). But see Hibbitts, supra note 1, at 299-300 (arguing that "prestige will not necessarily win someone tenure and promotion" since positive reviews of articles placed in nonelite journals and even unpublished articles can still win promotion).

${ }^{74}$ Cf. Stephen R. Heifetz, Efficient Matching: Reforming the Market for Law Review Articles, 5 GEO. MASON L. REv. 629, 637-38 (1997) (asserting that stability in the article selection process happens when article placement in law reviews accurately signals article quality, and that unstable matches are produced by exploding offers since, "if professors are being forced to place pieces in lesser [law reviews] because of the time frame ... their careers will be hurt" (quoting Lisa Anderson, Law Journals Attack "Shopping" of Manuscripts, N.Y. TIMES, July 12, 1995, at B6) (alterations in original)).

${ }_{75}$ This is indeed speculation on my part; as a student, I am not in a position to confirm or dispute the idea that faculty members use article placement as a proxy for quality. The commentary here simply points out some implications if it is true that faculty members use article placement as a proxy for quality. 
doctrinal analysts. Others, who may be good social scientists, are not appointed or promoted because they do not impress the doctrinal analysts. ${ }^{76}$

If this is still true, then the faults of students are shared by faculty-it's just a matter of degree. Posner's comments in the prior article extend his criticism of students to faculty, making one wonder if he is really criticizing students or if he is simply criticizing lawyers without Ph.D.'s.

Of course, it is problematic if students' error rate in selecting articles is extended to the career decisions of law schools. However, this should be addressed by ensuring that article placement is not a factor in career decisions, not by demanding a switch to a world where interdisciplinary articles are published only in faculty-edited specialty journals. If the only outlet for one's work were through specialty journals edited by peers, creativity and innovative ideas might be stifled. ${ }^{77}$

The important point is that promotion and tenure decision making and article selection have different needs in terms of processes and criteria. As a result, promotion and tenure processes should not rely on article placement to indicate article quality. Similarly, promotion and tenure concerns should not affect the article selection process. Professors may be right to be anxious about the relation between article placement and academic success, but the remedy is not to make article selection more restrictive.

\section{ARTICLE EDITING}

The critique of student competence does not stop at article selection. In the realm of editing, students are seen as incompetent pri-

${ }^{76}$ Richard A. Posner, The Present Situation in Legal Scholarship, 90 YALE L.J. 1113 , 1121-22 (1981).

${ }^{77}$ See Vitiello, supra note 26, at 941 ("For those who aspire to say something new and creative about the law, I urge them that their chances of finding a home for their work product is more improved with student editors than with peers who have more turf to protect in the great turf wars."). Professor Frances Olsen provides a pointed insight into the turf wars at stake:

I note that Richard Posner is quite willing for student-run law reviews to publish conventional, doctrinal articles, if only they would refrain from publishing exactly the kinds of articles that in my view it is so important to have published [including feminist jurisprudence and critical race theory]. Although "law and economics" presumably would also fall outside the "doctrinal" category ... the Journal of Legal Studies will publish any law and economics articles Posner wishes to have published.

Frances Olsen, The Role of Student-Run Journals in Opening North American Law, 39 ALTA. L. REV. 678, 683 (2001) (citation omitted). 
marily because students are not professional editors or even writers. ${ }^{78}$ "Because the students are not trained or experienced editors," says Posner, "the average quality of their suggested revisions is low. Many of the revisions they suggest (or impose) exacerbate the leaden, plethoric style that comes naturally to lawyers (including law professors)." "79 Judge Posner builds on other commentators' critiques here, especially those of Professor Lindgren.

Lindgren has asserted that students can go astray when it comes to grammar, usage, and style. ${ }^{80}$ In fact, as Professor Lindgren declares, “ $[\mathrm{m}]$ any student editors haven't read enough English literature to develop an ear for good writing." ${ }^{81}$ Both Posner and Lindgren portray student editors as overly intrusive and nit-picky. ${ }^{82}$ When it comes to substantive editing, students' weaknesses in the subject matter, as described in Part III, are also perceived to limit their ability to do well. ${ }^{83}$

${ }^{78}$ See Sanger, supra note 43, at 517 ("Most student editors have likely had no editorial experience before sitting down to your paper other than having had their own work hacked to bits by students who experienced the same thing the year before."); see also Posner, Against Law Reviews, supra note 1, at 57 (comparing scholarly journals in other fields to law reviews, noting that law reviews' "staffs are large, but the members, being students, are inexperienced both in law and in editing"). But see id. (describing a previous era of doctrinal analysis in law review publications, where students "were competent editors of law professors' articles with an incentive to do a good job").

${ }^{79}$ Posner, Against Law Reviews, supra note 1, at 58. "These inexperienced editors, preoccupied with citation forms and other rule-bound approaches to editing, abet the worst tendencies of legal and academic writing." Posner, Future of the Law Review, supra note 1 , at 1134

${ }^{80}$ Professor Lindgren describes the disagreements he has had with students over English usage, grammar, and style as follows:

Listing the couple hundred style errors introduced into a manuscript by "editors" and attaching excerpts from respected style texts to illustrate these errors is time-consuming, frustrating, and divisive. When those texts conflict with a bogus authority such as the Texas Manual on Style, as they often do, it is sometimes impossible to keep my prose from sounding as if it were written by an above-average third-year law student.

Lindgren, Fear of Writing, supra note 1, at 1678. He notes the case of the law review editor who did not know the proper usage of the word "the," as well as a number of other "abuses" of student editors. Lindgren, Manifesto, supra note 1, at 528-31.

${ }^{81}$ Lindgren, Manifesto, supra note 1, at 531.

${ }^{82}$ See Posner, Against Law Reviews, supra note 1, at 58 (lamenting that student editors "often torment the author with stylistic revisions"); see also J.C. Oleson, You Make Me [Sic]: Confessions of a Sadistic Law Review Editor, 37 U.C. DAVIS L. REV. 1135, 1144 (2004) ("The editor knows that the authors will fear and tremble when the FedEx envelope arrives, and this feels good.").

83 "Submissions in 'law and...' fields magnify the bad effects of the inexperience of student editors and their failure to use peer review to separate the wheat from the chaff. Apart from acute problems of quality control, neither author nor reader is likely to benefit from the editing process." Posner, Against Law Reviews, supra note 1, at 58. 
Students "are rarely competent to offer substantive improvements, or catch analytic errors, or notice oversights in research, in nondoctrinal articles," Posner has written. ${ }^{84}$ Students might overlook a weak argument that needs refinement, while trying to tinker with arguments that they are too naive to know should not be changed. In addition, it has been said that the student psyche relies too heavily on convention, because of the insecurity of being, in effect, only a student. ${ }^{85}$ Thus, the law review conventions of heavy footnoting, ${ }^{86}$ The Bluebook or other manual adherence, impersonal tone, and roadmap format do not change. ${ }^{87}$ Finally, the strange power difference between students and professor-authors makes students inappropriate in the role of editor, causing editorial conflict. ${ }^{88}$ Many of these reasons account for Judge Posner's conclusion that " $[\mathrm{n}]$ ot only is the marginal product of student editing frequently less than the marginal cost, it sometimes is negative." ${ }^{89}$ In fact, given the weaknesses of students, Posner has recommended that students withdraw from the job of close editing. ${ }^{90}$

Much of the rebuttal to these arguments has been published before. Law school students are adults, with undergraduate degrees and sufficient English language experience to perform the role of editor. ${ }^{91}$

${ }^{84}$ Posner, Future of the Law Review, supra note 1, at 1134.

${ }^{85}$ Law review editors "are suddenly placed in positions of responsibility for which they are grossly unsuited .... They are insecure about their writing and editing skills and have little hope of acquiring these skills before they'll need them. So they retreat to the safety of the elaborately anal world of stigmatic rules." Lindgren, Fear of Writing, supra note 1 , at 1679 . More succinctly, "[a]s has been argued in the sociolinguistics literature, a rule-oriented approach to writing is a reflection of linguistic insecurity." Lindgren, Manifesto, supra note 1, at 531.

${ }^{86}$ As the reader has undoubtedly noticed, this Comment exemplifies the muchmaligned tendency to overfootnote. But, I like footnotes; I like the fact that the reader may choose to read the short or long version of my paper. And, in an age where web surfing has become commonplace, we should be more welcoming of the nonlinear thought process. Footnoting is the low-tech forerunner of the hypertext of the web.

87 " $[\mathrm{T}]$ he problems reside in the unchangeable structure of the institution-the inherent inexperience and immaturity of student editors, the absence of the spur of competition, and the absence of continuity, which reduces the incentive to make changes . . . ." Posner, Future of the Law Review, supra note 1, at 1135.

Cf. Oleson, supra note 82, at 1145 ("The law review... affords members the unique opportunity to reclaim some of the personhood that has been stripped of them throughout the first-year curriculum and to punish those [professors] who have humiliated them. Revenge is wrought with red pens." (citations omitted)); Sanger, supra note 43, at 518 (noting "the awkwardness of the professor-student relationship").

${ }^{89}$ Posner, Future of the Law Review, supra note 1, at 1135.

${ }^{90}$ See id. at 1138 ("Recognizing their limitations as manuscript editors, law review staff should forswear line-by-line editing.").

${ }^{91}$ Professor Nichols notes: 
Some authors have claimed that the situation is not as bad as it has been made out to be, ${ }^{92}$ especially because law reviews have implemented changes in response to authors' complaints. ${ }^{93}$ Others have pointed out that the benefits of student-run reviews outweigh the editing difficulties and awkwardness. ${ }^{94}$ These benefits include the reviews' ample manpower for technical assistance and research, their assistance in making arguments clearer and more understandable, and the fact that students do not need to be paid to do the work. Finally, certain law review conventions have been defended as being useful to scholarship, justifying student adherence. ${ }^{95}$

Beyond this, it is worth noting that the editing process used by law reviews, while it can be frustrating to authors, is designed to counter the deficiencies that students may have as editors. Although editing procedures vary among law reviews, the common thread is multiple rounds of editing, with each round involving several students. Any

There is no reason to believe that law school students cannot edit. Law school students are all college graduates and in general have high verbal skills. Those selected for law review, by whatever method, also exhibit some ability to organize thoughts and express them clearly. All of these qualities are the essential skills for editing qua editing.

Nichols, supra note 32, at 1129 (citations omitted). Also, a humble remark comes from Professor Jones, who said:

Having professors edit law reviews sounds best the first time you hear it. It resonates with the presumption that an enormous gap exists between teacher and taught, that teachers are better at legal thinking and writing than their students.... On the contrary, any year, any law school produces graduates better at thinking and communicating about the law than some or all of its faculty. This is not meant as an admission of our collective shortcomings, but as a declaration of our achievement.

Jones, supra note 17 , at 241 . Of course, this observation may not apply to thinking and writing about interdisciplinary fields. However, it is a reminder that the professorstudent gap is not necessarily one of maturity or intellectual capability.

${ }^{92}$ See Olsen, supra note 77, at 683 ("[W] hile there are some reasonable criticisms of student-run law journals, many of the criticisms are unreasonable or irrelevant. Moreover, there are many advantages to the current system of student-edited journals."); Richard Delgado, Eliminate the "Middle Man," 30 AKRON L. REV. 233 (1996) (defending student editors' value in improving manuscripts).

93 Michael Vitiello, In Defense of Student-Run Law Reviews, 17 CuMB. L. REv. 859, 874 (1987) ("In fact, student-run law reviews are responding to criticism. Prominent law reviews are accepting nontraditional commentaries and other innovative works."); Vitiello, supra note 26, at 930 ("I find that there has been positive change in format and content of what many law reviews are publishing.").

${ }^{94}$ Wendy J. Gordon, Counter-Manifesto: Student-Edited Reviews and the Intellectual Properties of Scholarship, 61 U. CHI. L. REV. 541, 542 (1994) ("[T] he virtues of the student-edited review outweigh its vices.").

${ }_{95}$ See id. at 547-49 (arguing that footnoting and literature reviews are helpful both to readers and to fellow scholars). 
given student may not have prior editing experience, but from the collection of those involved, good revisions are suggested and accepted.

More specifically, in each round, several students suggest changes, with varying quality. The sum of these changes are reviewed by a board member within the review who eliminates erroneous or illadvised suggestions, and sends the results to the author to accept or reject individually. The process is then repeated. At each stage, the process is designed to both reveal higher quality editing and maintain the manuscript's quality by keeping the author involved. Although authors are understandably frustrated by the repeated revisions, the changes to their work that law reviews submit to the author are merely suggestions. In the end, the author has the authority to accept or reject. The process of edit author-review, edit author-review may seem inefficient, but it is the best way to ensure that the end product receives the best editing, given the varying editing capabilities within the review.

As Judge Posner points out, the process is time-consuming for the author: "To student editors, the cost of an author's time is zero, and the author is usually subjected not to one, but to two or three rounds of editing." Moreover, as Professor Sanger has noted, "many of us [authors] have spent many hours resuscitating sentences, paragraphs, lines of argument, and sometimes whole manuscripts that have been edited nearly to death." ${ }^{97}$ Finally, commentators have pointed out perceived perverse effects of the system: "Nor is it pleasant for a mature scholar to be subjected to the supreme and irrevocable judgment of incompletely trained students. This may have a discouraging effect upon competent writers, and may even impair creative work . ..." ${ }^{98}$

It is important to acknowledge that the editing process consumes significant resources, both in terms of author- and student-editor time. Yet, it is because the author's knowledge, attention, and time are so valuable that the process calls for her involvement. It would be more appropriate to say that the cost of an author's time is high, while any individual student editor's time is much lower.

${ }^{96}$ Posner, Against Law Reviews, supra note 1, at 58; see also Sanger, supra note 43, at 523 ("After what is often already an immense investment in time, just when you think you've negotiated the final version of the paper, new revisions come back ... from someone higher on the editorial chain and the process of reclaiming your work begins anew. This is ... demoralizing for the author ....”).

${ }^{97}$ Sanger, supra note 43, at 513-14.

${ }^{98}$ Nussbaum, supra note 11 , at 381 . 
Because student time is less valuable, the process combines the considerable efforts of many students; because students' expertise in editing varies highly, the process involves several rounds of edits, each involving multiple students. Simply put, quality control in editing is created by having as many eyes on the manuscript as possible. ${ }^{99}$ When an author receives a marked-up manuscript, it is not supposed to be a final edit. ${ }^{100}$ It is a work in progress-the author herself completes the final edit by accepting or rejecting changes suggested in the last round.

In other words, when an author rejects suggestions in the last round of editing, the author is not "undoing" the students' ill-advised work; instead, the author is acting as the final filter in the editing process itself. Viewed in this way, the editing process becomes inelegant but makes sense. Rather than being the result of "a combination of student age, circumstance, and power . . . coupled with institutional undersight and an exaggerated respect for stylistic norms," ${ }^{101}$ the iterative process is the result of the need to involve the author.

When editors are not professionals, a more collaborative process between author and editors improves the outcome. ${ }^{102}$ In this vein, the 1994 Executive Board of the Chicago-Kent Law Review noted that it takes a certain amount of experience to know which editorial suggestions are important enough to implement-in other words, there may be very many ways to improve a manuscript, but not all of them

${ }^{99}$ For some authors, the process is doubly frustrating because it seems as if the best quality of students is still not good enough: "I would readily admit that I have written few manuscripts which an excellent edit could not improve; however, I must state that my work has practically never received such editing." Tobias, supra note 22, at 539. Certainly students vary considerably in their ability to contribute to an article, see Epstein, supra note 5, at 87-88 (noting the high variance in editorial competence), but many manuscripts are significantly improved by the editing process. Comment, The Symposium Format as a Solution to Problems Inherent in Student-Edited Law Journals: A View from the Inside, 70 CHI.-KENT L. REV. 141, 147 (1994) ("[I]t has been our experience ... that without extreme editing some faculty articles we have published would have been virtually unintelligible.”).

${ }^{100}$ Professor Maggs recommends that "editors who look at articles late in the editorial process generally [not] revisit material other editors already have approved." Gregory E. Maggs, Just Say No?, 70 CHI.-KenT L. REV. 101, 110 (1994). But this is missing the point-earlier stages of editing do not approve anything, but simply work to revise. The author does the approving. What definitely should be avoided is having multiple editors suggest identical revisions, which the author has already rejected.

${ }^{101}$ Sanger, supra note 43, at 517.

${ }^{102}$ See Gordon, supra note 94, at 544-45 ("[T] he student editors sometimes recommend tremendously helpful structural changes. . . Indeed, nearly every one of my articles has been stronger coming out of the editorial process than it was going in."). 
should be pursued. ${ }^{103}$ Since many students do not have this kind of experience, it is best that student editors adopt a less aggressive editing policy, but still "make all suggestions that we think would improve the article, and leave the ultimate decision regarding non-technical edits in the control of the author." 104

\section{CONCLUSION}

In summary, there is much to be said for the competence of students as editors of law reviews. With students as editors, we can rest assured that not only will creative and untraditional theses be voiced, but that all good manuscripts will find a forum for publication. Over time, student-edited law reviews have developed processes, including preemption checks and multiple-round editing, that compensate for the lack of specialized knowledge and variance in editorial capability of students. Preemption checks not only reveal whether an article under submission is unique, but also provide the important opportunity for students to quickly digest the subject concerned. Involving several students in the same edit pools the knowledge and capabilities that students do have-and involving the author extensively in the editing process results in a better work product. Law reviews are not perfect, and today's reviews must continue to emphasize quality control and innovation. However, students are well equipped to pursue reviews' scholarly goals.

More precisely, it must be acknowledged that the process does not have to be perfect; student-edited journals vie for prestige in the academic community by maintaining a portfolio of high quality articles, but do not have to accept every good article. For authors who believe the stakes are too high, it rests on them to convince their peers to accord tenure and promotion based on the value of the scholarship and not its placement. In response to Judge Posner, I suggest that the intellectual battle over interdisciplinary theses take place in the hallowed halls of the academy and through a literature rich in critique and dialogue. The publication process should not be shifted in such a way as to foreclose debate.

${ }^{103}$ See Comment, supra note 99, at 150-51 (illustrating how too many editing suggestions can be detrimental, even when each suggestion alone would improve the article).

${ }^{104} I d$. at 151 (emphasis added). Thus, even though too many suggestions can be detrimental, there is no way around it-one must err on the side of offering more rather than less. 